\title{
TAMAN ALUN-ALUN: PRODUKSI RUANG (SOSIAL) DAN KEPUBLIKAN
}

\author{
Justito Adiprasetio $^{1}$ Sandi Jaya Saputra ${ }^{2}$ \\ ${ }^{1,2}$ Program Studi Jurnalistik, Fakultas Ilmu Komunikasi, Universitas Padjadjaran. \\ E-mail : \\ 1justitoadiprasetio@gmail.com \\ 2 sandijayasaputra85@gmail.com
}

\begin{abstract}
Since the beginning of revitalization, Taman Alun-alun Bandung is expected to be a public space where people can interact with each other and build a healthy social order. Public space when viewing on the concept of Juergen Habermas, is a space within which there is participation and plural public consolidation and across classes and social structures with an emancipatory agenda. This research is by ethnography method which seeks to examine how so far Taman Alun-alun Bandung carry out its function as a public space of Bandung city residents. This research uses two big concepts namely Public Space from J uergen Habermas and Production of Social Space from H enrik Lafebvre, seeks to describe how social production space and nuance of publicity in the Park Taman Alun-alun Bandung. In the praxis level Taman Alun-alun Bandung can not be said to successfully perform its function as a representational spaces for community participatory activities. Created public spaces become pseudo, considering the imprisonment it makes imagined publicity can fill Taman Alun-alun Bandung not achieved.
\end{abstract}

K eywords: city square, Park, Habermas, Lafebvre, public spaces

\begin{abstract}
Abstrak
Sejak awal revitalisasi, Taman Alun-alun Bandung diharapkan dapat menjadi ruang publik tempat di mana masyarakat dapat saling berinteraksi dan membangun tatanan sosial yang sehat. Ruang publik apabila menilik pada konsep Juergen Habermas, adalah ruang yang didalamnya terdapat partisipasi dan konsolidasi publik yang plural dan melintasi kelas serta struktur sosial dengan agenda emansipasi. Penelitian ini mengunakan metode etnografi, yang berupaya memeriksa bagaimana sejauh ini Taman Alun-alun Bandung menjalankan fungsinya sebagai ruang publik warga kota Bandung. Penelitian ini menggunakan dua konsep besar yaitu Ruang Publik dari Juergen Habermas dan Produksi Ruang Sosial dari Henrik Lefebvre, berupaya mendeskripsikan bagaimana ruang produksi sosial dan nuansa kepublikan di Taman Alun-alun Bandung. Dalam tataran praksis Taman Alun-alun Bandung tidak dapat dikatakan berhasil menjalankan fungsinya sebagai representational spaces bagi aktivitas partisipatif masyarakat. Ruang publik yang tercipta menjadi semu, mengingat keberjarakan tersebut membuat kepublikan yang dibayangkan dapat mengisi Taman Alun-alun Bandung tidak tercapai.
\end{abstract}

Kata Kunci: Alun-alun Bandung, Taman Habermas, Lafebvre, Ruang Terbuka Umum 


\section{Pendahuluan}

Sejak kepemimpinan Ridwan Kamil, Taman-taman di kota Bandung mengalami revitalisasi besar-besaran. Taman-taman yang sebelumnya sempat tak terawat, dan tersisihkan laju pembangunan, diperbaiki secara bertahap. Ridwan Kamil menuturkan, bahwa proyek revitalisasi dilakukan untuk meningkatkan persentase Ruang Terbuka Hijau (RTH), yang secara ideal berjumlah 30 persen, sekaligus untuk membuka ruang sosial yang dapat dimanfaatkan oleh masyarakat. ${ }^{6}$ Salah satu taman yang menjadi andalan kota Bandung adalah Taman Alunalun Bandung, selain karena berletak sangat strategis, dan menjadi jantung dari kota Bandung, ukuran Taman Alun-alun Bandung menjadi sangat ideal sebagai ruang publik partisipatif.

Sejak awal pembangunannya tamantaman di kota Bandung diharapkan dapat menjadi ruang publik (public sphere) tempat di mana masyarakat dapat saling berinteraksi dengan baik; bahkan Ridwan Kamil menyebutkan taman kota dapat menghasilkan generasi yang toleran sebagai akibat dari interaksi sosial yang terdapat di dalamnya. Taman kota, sebagai ruang publik dianggap dapat menjadi tulang punggung dari demokrasi.

Pernyataan akan potensi dalam proyek revitalisasi taman-taman kota di Bandung yang dituturkan oleh Ridwan Kamil sebelumnya juga diafirmasi oleh Ketua Tim Pertimbangan Kebijakan Publik Wali Kota Bandung, Dede Mariana, saat menghadiri "Refleksi Dua Tahun Kepemimpinan Ridwan Kamil \& Oded Danial di Kota Bandung" di Gedung Indonesia Menggugat, Bandung. Bahwa ruang-ruang publik, di kota Bandung perlahan mulai tumbuh, "saya kira adanya ruang-ruang publik yang mulai tumbuh, muncul ikon baru yang sebetulnya

http://properti.kompas.com/read/2015/02/04/232605821/Men uju.Kota.Bahagia.Bandung.Perbanyak.Taman merevitalisasi yang ada"7 Taman-taman kota yang telah dibangun dan dibuka, dijustifikasi telah menjadi ruang-ruang publik bagi masyarakat. Tercatat, pemerintah telah merevitalisasi 23 taman tematik, dengan rencana jangka panjang membuat 1 taman kewilayahan per Rukun Warga $(\mathrm{RW})^{8}$. Pemerintah kota sejauh ini mengalokasikan dana sebesar 42 Miliar Rupiah, untuk proyek revitalisasi taman tersebut ${ }^{9}$

Salah satu tolok ukur, keberhasilan dari pembangunan ruang publik di taman kota, Bandung dalam versi pemerintah kota Bandung adalah terjadinya peningkatan index of happiness (indeks kebahagiaan) masyarakat kota Bandung. Hal tersebut disampaikan oleh Kepala Seksi Penataan da Kepala Seksi Penataan dan Pembangunan Taman Dinas Pemakaman dan Pertamanan Kota Bandung, Rikke Siti Fatimah "Tujuan kita memang mendorong warga mendapatkan tempat hiburan selain pusat belanja di kota Bandung. Jadi masyarakat bisa mengisi aktivitasnya di taman. Taman selain berfungsi secara ekologis juga menjadi sarana sosial, budaya, rekreasi, edukasi, olahraga, estetika, juga menjadi tempat warga atau komunitas berkreasi," tutur Rikke seperti yang dicatat oleh Kompas.com. ${ }^{10}$ Hal tersebut juga diafirmasi oleh Iwan Sugiono, Kepala Bidang Pertamanan DPKP3 Kota Bandung.

Dari hasil survey untuk mengukur efektifitas taman di Bandung, hasilnya $80 \%$ warga Bandung yang mengakses taman merasa lebih senang dan bahagia. Hal tersebut berkorelasi dengan index of happiness di kota Bandung yang meningkat. Taman berkontribusi terhadap index of happiness khalayak

\footnotetext{
${ }^{7}$ http://www.rappler.com/indonesia/107104-dua-tahunkepemimpinan-ridwan-kamil-oded-danial

${ }^{8} \mathrm{http}: / /$ bandungkita.net/2016/12/ridwan-kamil-sebut-taman-

kota-bisa-lahirkan-generasi-toleran/

${ }_{9}^{9}$ http://www.pikiran-rakyat.com/bandung-

raya/2016/04/12/pemkot-gelontorkan-rp-42-miliar-untukrevitalisasi-taman-366515 10

http://properti.kompas.com/read/2015/02/04/232605821/Men uju.Kota.Bahagia.Bandung.Perbanyak.Taman
} 
Bandung, bahawa semua golongan bisa memanfaatkan lahan tersebut (taman) tanpa harus membayar. Dengan adanya taman, harapannya mempu menurunkan tingkat "emosional" masyarakat.

(Iwan Sugiono, Kepala Bidang Pertamanan DPKP3 Kota Bandung - wawancara).

Keberhasilan tumbuhnya ruang publik, tempat di mana aktivitas interaksi dalam masyarakat, (semestinya) bisa menembus batas kelas dan stratifikasi sosial menurut wakil dari pemerintah Kota Bandung, dapat diukur oleh suatu konsep abstrak, yaitu kebahagiaan. Kebahagiaan yang barangkali (dan akan coba dibuktikan kemudian dalam penelitian ini) diakibatkan oleh kegiatan paling umum yang sangat mudah kita saksikan dari berbagai aktivitas masyarakat di Taman Alun-alun Bandung: Selfie dan bermain Bersama keluarga.

Terdapat pertanyaan yang belum terjawab oleh pemerintah, apakah motivasi menciptakan ruang publik, yang sedari awal menjadi landasan proyek revitalisasi taman berkelanjutan tersebut memang memiliki relevansi dengan publik dan memiliki corak 'kepublikan' - interaksi yang deliberatif dalam masyarakat pada tataran praktikal?

Apakah ruang publik sebagai sebuah konsep yang coba diterapkan, dapat direduksi sekadar menjadi tempat orang bahagia berkerumun dan melaksanakan berbagai macam kegiatan masing-masing tapi secara bersamaan, sembari mereduksi dimensi politik, dari publik yang seharusnya menjadi landasan dari keberadaan public sphere itu sendiri?

Pertanyaan-pertanyaan tersebut dapat dijawab bila konsep publik di dalam slogan 'ruang publik' yang menjadi motivasi awal pembangunan taman-taman kota Bandung dapat dimengerti dengan baik. Di mana tolok ukur keberhasilan ruang publik, meminjam konsep Juergen Habermas terkait public sphere, seharusnya bukanlah hanya soal kebahagiaan, namun yang paling mendasar adalah, terjadinya partisipasi pluralitas publik dan konsolidasi publik pada suatu ruang tertentu yang melintasi kelas dan struktur sosial dilandaskan dan untuk mencapai emansipasi. Partisipasi pluralitas publik, yang memungkinkan terciptanya kegiatan bersama lintas kelas (sosial), terorganisir dan kolaboratif di suatu tempat, entah itu kegiatan seni yang berlanjutan, diskusi 'publik' atau kegiatan-kegiatan lain dengan tujuan deliberasi (Habermas, 1991).

Sedangkan merujuk pada Nancy Fraser, bahwa ruang publik yang berisi dialektika antara pluralitas-pluralitas, hanya dimungkinkan bila tidak ada ketimpangan struktur sosial. Pra-syarat dari keberadaan ruang publik, adalah emansipasi, kesetaraan dalam posisinya di struktur sosial, di mana ekonomi adalah salah satu bagian di alamnya. Ruang publik tidak hanya dapat mengandalkan apa yang disebut politics of recognition dari pluralitas publik-publik yang berkontestasi. Namun diperlukan dorongan transformasi ekonomi sosial masyarakat, hal yang menjadi pra-syarat dari 'paritas partisipatif' yang terdapat di dalam ruang publik. Pada saat yang bersamaan, kita dapat mengetahui bahwa disparitas ekonomi di kota Bandung, semakin melebar. Badan Pusat Statistik (BPS) mencatat pada tahun 2016, warga miskin di Kota Bandung menyentuh angka 10 persen dari total penduduk kota Bandung. ${ }^{11}$ Jumlah tersebut meningkat bila dibandingkan dengan angka yang tercatat pada tahun 2015. ${ }^{12}$ Bila merujuk pada argumen Fraser, maka semakin jauh Bandung dari proses penciptaan ruang publik (tentu dengan corak politik yang demokratis dan deliberatif) (Fraser, 1990).

Merujuk pada Henrik Lefebvre, bahwa (social) space is a (social) product, ruang (sosial) tidak akan dapat muncul begitu saja tanpa konstruksi sosial (berdasarkan nilai dan

\footnotetext{
11

http://nasional.republika.co.id/berita/nasional/daerah/16/04/0 6/o57bg2366-10-persen-warga-kota-bandung-hidup-miskin

${ }^{12}$ http://jabar.bps.go.id/new/website/brs_ind/brsInd20160104140758.pdf
} 
produksi sosial tentang makna) yang menjadi penopangnya; taman kota tak akan bisa menjadi ruang sosial yang demokratis, bila tidak memiliki basis sosial yang demokratis pula. Vice-versa (Lefebvre, 1991: 26). Bahwa ruang, tidak dapat berdiri sendiri tanpa basis sosial yang ada, tanpa konstruksi sosial tentang ruang yang menjadi dasar dari keberadaan ruang itu sendiri. Gestur-gestur (habitus/kebiasaan), infrastuktur, dan aktivitas yang terdapat dalam konteks keberuangan dari taman kota adalah cerminan dari konstruksi sosial yang ada.

Dengan paparan sebelumnya, penelitian ini memfokuskan diri pada bagaimana relasi antar ruang, aktivitas sosial (partisipasi publik), kondisi material yang terdapat dan melekat pada Taman Alun-alun Bandung dengan tujuan awal pembangunannya, yaitu menjadi ruang publik.

Menggunakan dua konsep besar yaitu Ruang Publik dan The Production of Space, penelitian ini ingin melihat sejauh apa partisipasi publik dan kondisi 'kepublikan' dapat meruang di Taman Alun-alun Bandung. Dua konsep besar tersebut akan dicangkokkan dalam metodologi etnografi yang memberikan fokus utama pada relasi space sebagai sebuah representasi ruang yang digunakan oleh manusia dan place sebagai kondisi material. Suatu pendekatan yang melihat bagaimana lapisan-lapisan kebudayaan serta kondisi-serta pra-syarat yang menopang lapisan-lapisan kebudayaan tersebut, sehingga dapat bekerja dalam suatu ruang (space dan place) tertentu, dalam konteks ini Taman Alun-alun di kota Bandung.

Merujuk pada fokus penelitian yang telah ditetapkan maka penelitian memiliki tujuan untuk mendapatkan pemahaman terkait:

1. Hubungan antara ruang dan relasi sosial di Taman Alun-alun Bandung?

2. Pra-kondisi dari hubungan ruang dan relasi sosial di Taman Alunalun Bandung.
3. Kondisi ruang publik yang terbentuk di Taman Alun-alun Bandung?

\section{Kajian Pustaka dan Kerangka Pemikiran}

Seperti yang telah dituturkan sebelumnya, penelitian ini akan menggunakan dua konsep besar yaitu Ruang Publik dari Juergen Habermas dan Produksi Ruang dari Henrik Lefebvre. Dua konsep besar tersebut akan menjadi bangunan teoritik untuk membongkar bagaimana kondisi 'ruang publik' di Taman Alun-alun Bandung.

\section{a. Ruang Publik (Public Sphere)}

Ruang publik dalam kacamata Habermasian merupakan, ruang di mana anggota masyarakat terikat satu sama lain dengan pondasi rasionalitas untuk melakukan kegiatan dan diskusi publik secara kritis. Ruang publik menyaratkan egaliterianisme (kesetaraan antar subjek-subjek di dalamnya), upaya pembentukan formasi opini publik (yang berarti segala macam aktivitas harus memiliki impact dalam posisinya sebagai pembentuk opini publik), penghargaan terhadap kebebasan berpendapat, berekspresi, kebebasan berasosiasi dst, serta pengupayaan diskusi pada segala hal yang memengaruhi 'publik' (Habermas, 1991: 25-55). ${ }^{13}$

Apa yang dimaksud oleh Habermas dengan diskusi publik tak selalui secara vulgar menunjuk pada diskusi terkait politik elit semata, namun juga tentang seni, budaya dan lainnya. Habermas memberikan contoh dalam bukunya, bahwa di abad ke-18 salah satu bentuk dari ruang publik adalah kafekafe tempat orang-orang meminum kopi. Kafe-kafe yang pada saat itu merupakan pusat dari diskusi tentang seni dan kritik sastra, di luar ekonomi dan politik elit. Pada akhirnya dimensi politik yang terbaca dalam diskusi

\footnotetext{
${ }^{13}$ Habermas, Jürgen (German (1962) English Translation 1989). The Structural Transformation of the Public Sphere: An Inquiry into a Category of Bourgeois Society. Thomas Burger. Cambridge Massachusetts: The MIT Press. 27-52.
} 
dan aktivitas di ruang publik, tak hanya politik dengan "P" besar namun politik yang menyublim dalam segala sendi kehidupan masyarakat yang berpartisipasi dalam ruang publik itu sendiri. Dalam konsep Habermas, maka ruang publik adalah suatu wahana diskursus masyarakat, tempat terjadi diskusi dan kegiatan yang demokratis dan deliberatif. Hal yang membuat ruang publik niscaya bersifat partisipatif.

\section{b. "The Production of Space."}

Ruang dalam kacamata Lefebvfre adalah hasil dari konstruksi sosial yang kompleks, di mana konstruksi sosial tersebut disusun oleh serangkaian nilai, dan produksi sosial dari makna) yang memengaruhi praktik spasialisasi dan persepsi akan ruang.

Lefebvre membangun kerangka konseptual apa yang ia sebut dengan 'a conceptual triad' yang menjelaskan bagaimana ruang itu terbentuk.

1. Spatial practice. Suatu bagian yang menunjukkan bagaimana praktik produksi dan reproduksi atas relasi spasial antara objek dan produk. Relasi antara objek (dalam kondisi material) dengan produk sosial yang dibentuk oleh objek-objek tersebut (Lefebvre, 1991: 33).

2. Representation of Space. Pembentukan ruang, melalui pengotak-kotakkan ruang yang dihasilkan dari 'order'-pengaturan yang melibatkan pengetahuan, tanda, kode, dan relasi lainnya. Hal yang membuat ruang terbelah, dan menghasilkan ruang-ruang konseptual dan spesifik seperti ruang yang diproduksi ilmuan, ruang peneliti urban, ruang teknokrat, dst saat mengidentifikasi ruang (Lefebvre, 1991: 30-38).

3. Representational Spaces. Ruang dalam dimensi 'penduduk' dan 'pengguna', di mana mereka hidup dalam ruang yang merupakan hasil dialektika dari Spatial Practice dan
Representation of Space. Hasil dialektika antara relasi subjek-objek (kondisi material dan produksi sosial dari kondisi material itu) dengan kategorisasi ruang yang dibangun via pengetahuan dan tanda-tanda oleh mereka yang otoritatif (Lefebvre, 1991: 39).

Dengan premis awal tersebut, Lefebvre menganalisis bagaimana kapitalisme berelasi langsung dengan praktik pembentukan ruang, dan vice versa. Lefebvre berargumen bahwa produksi sosial yang menghasilkan urban space (ruang urban) adalah fundamental/penopang dari proses reproduksi kapitalisme. Produksi sosial akan ruang, pada akhirnya rentan dan seringkali digunakan oleh kelas hegemonik (berkuasa) sebagai alat untuk menguatkan dominasinya.

\section{O bjek dan M etode Penelitian}

Penelitian ini akan menggunakan Etnografi, di mana fokus awal penelitian ini adalah melihat sejauh mana taman-taman di kota Bandung menjadi 'ruang publik' sekaligus memetakan praktik-praktik kebudayaan yang mengisi Taman Alun-alun Bandung dan. Setelah peta praktik kebudayaan telah didapatkan, fokus akan berpindah pada pembacaan pra-kondisi yang menjadi penopang dari praktik-praktik kebudayaan dan 'ruang publik' itu dapat terjadi.

Teknik Pengumpulan data yang digunakan dalam penelitian ini adalah:

1. Observasi. Observasi yang akan dilakukan dalam penelitian ini adalah observasi partisipatif. Di mana, peneliti akan mengamati dengan seksama lapisan-lapisan kebudayaan, seperti interaksi sosial, pembentukan identitas, aktivitas, dst yang terdapat di Taman Alun-alun Bandung.

2. Wawancara. Wawancara dilakukan kepada subjek-subjek yang berpartisipasi pada aktivitas-aktivitas di Taman Alun-alun Bandung, serta aktivis dan pemerhati yang 
memberikan perhatian besar terhadap ruang publik tersebut.

\subsection{Teknik Analisis Data}

Bogdan dan Biklen (1982) menjelaskan bahwa teknik analisis adata adalah proses penyusunan dan pengkajian secara sistematis data-data yang didapatkan dari lapangan, seperti transkrip wawancara, catatan lapangan, dokumen-dokumen pendukung serta data-data lain untuk merengkuh pemahaman terkait fokus penelitian.

Terdapat beberapa tahap teknik pengolahan data yang akan menjadi bagian dari tahapan penelitian ini.

1. Reduksi data. Proses reduksi, di mana data-data yang didapat di lapangan akan dipilih, difokuskan, disederhanakan dan ditransformasikan menjadi sekumpulan data yang ramping dan relevan dengan pertanyaan serta fokus penelitian yang coba ditelaah. Reduksi data, akan dilakukan secara terus menerus selama proses penggalian data dilakukan.

2. Pengorganisasian data. Untuk membangun relasi logis antara satu data dengan data lain, dibutuhkan pengorganisasian atau kompresi informasi. Hal tersebut dilakukan, dengan tujuan untuk membangun relasi-relasi variabel di dalam fenomena sehingga fokus penelitian dapat terjawab, sehingga dapat menghasilkan simpulan.

3. Penyimpulan. Tahap terakhir adalah penarikan simpulan, yang sebelumnya didahului oleh proses verifikasi untuk mengecek ulang data-data dan variabel-variabel yang telah diorganisir.

\section{Hasil dan Pembahasan}

Taman Alun-alun Bandung pada dasarnya adalah representation of space, ruang dengan order awal sebagai 'ruang publik' bagi masyarakat. Tujuan pembangunan taman kota tertuang dalam pernyataan Ketua Tim Pertimbangan Kebijakan Publik Wali Kota Bandung, Dede Mariana, seperti yang telah disebutkan di bagian pendahuluan.

Sebagai ruang konseptual Taman Alun-alun Bandung dihadirkan sebagai ruang demokratis tempat di mana orang-orang berkumpul dan diharapkan dapat menjadi bagian dari sarana social engineering bagi masyarakat. Masyarakat dianggap bukan hanya sebagai sebagai subjek pasif, namun menjadi bagian yang berpartisipasi aktif dalam perencanaan pembangunannya. Visi dari Taman Alun-alun Bandung tersebut, sejalan dengan apa yang diutarakan oleh Iwan Sugiono, Kepala Bidang Pertamanan DPKP3 Kota Bandung:

"Secara garis besar, kami mewujudkan visi dan misinya kota Bandung, yaitu salah satunya Unggul, Aman dan Sejahtera. Selanjutnya kami juga mewujudkan strategi pembangunan kota Bandung, yaitu Inovasi, Desentralisasi dan Kolaborasi. Inovasi; melakukan inovasi diberbagai sektor untuk meningkatkan layanan publik, dalam hal pertamanan kami merawat keberkangsungan taman untuk khalayak. Desentalisasi; mendistribusikan pembangunan, dalam hal ini pembangunan dalam hal taman. Tujunnya agar tercapai pembangunan (taman) yang merata di setiap daerah. Kolaborasi; dalam strategi ini kami punya slogan, Bandung memanggil. Program ini membuka peluang untuk bekerja sama dengan warga, demi tercapainya pembangunan. Jadi siapapun bisa berkontribusi dalam pembangunan 


khususnya taman, dengan
membawa konsepnya ke pada
kami."
(Iwan Sugiono, wawancara)

(Iwan Sugiono, wawancara)

Agenda, tersebut menjadi terasa ideal di atas kertas melihat pada ihwal awal idealisasinya, di mana taman bersifat mendua, yaitu Taman Alun-alun Bandung merupakan suatu bentuk fasilitas pelayanan publik, tetapi di sisi lain, ia adalah ruang yang membutuhkan diskursus publik yang dinamis. Tidak hanya dalam hal perencanaan pembangunannya, juga untuk menjaga nuansa kepublikan Taman Alun-alun Bandung itu sendiri. Di mana salah satu tujuan dari sarana social engineering dari Taman-alun yang diharapkan oleh pemerintah daerah Kota bandung adalah seperti yang diutarakan oleh Ridwan Kamil, yaitu taman kota dapat menghasilkan generasi yang toleran sebagai akibat dari interaksi sosial yang terdapat di dalamnya. Taman kota, dalam kondisi ideal dibayangkan dapat sebagai ruang publik dianggap dapat menjadi tulang punggung dari demokrasi. Sebuah harapan atas mekarnya bunga-bunga demokrasi, setelah melalui fase panjang upaya untuk mereformasi jejak-jejak represif dan ideologis yang diwariskan oleh Orde Baru secara struktural (Kusno, 2009).

\subsection{Hubungan antara ruang dan relasi sosial di Taman Alun-alun Bandung.}

Pernyataan Ridwan kamil di sini dapat dibaca bahwa Taman Alun-alun Bandung sejalan dengan konsep Lefebvre - tidak dapat dihadirkan sekadar dalam dimensi spasial semata, namun lebih jauh harus ditunjang oleh dimensi sosial. Kedua dimensi yang memungkinkan Taman Alun-alun Bandung menjadi sebuah ruang kepublikan yang memiliki corak deliberatif bagi masyarakat demokratis. Taman Alun-alun Bandung adalah representation of spaces dari idealisasi demokrasi. Idealisasi tersebut diafirmasi oleh Ismail Reza, U rban Planner yang menetap di Bandung:
Dari dulu Bandung sudah terkenal dengan tamannya, hari ini tamantaman tersebut banyak direvitalisasi. Kota yang ideal adalah kota yang memiliki public realms yakni mengembalikan ruang pada masyarakat, ruang sebagai milik publik maka sepatutnya pemerintah membangun dan memberikan akses sebesar-besarnya terhadap publik. Perbedaaanya hanya pada wilayah estetik, yang akhirnya memberikan "nilai tambah" dari taman itu sendiri. Dulu taman dipandang hanya sebagai lokasi banyaknya tanaman.

(Ismail Reza, urban planner wawancara).

Namun, sekadar representasi ruang saja, tidaklah cukup. Idealisasi taman kota sebagai ruang publik membutuhkan dialektika langsung terhadap masyarakat. Taman Alunalun Bandung sebagai representational spaces, yang dibayangkan harus dilihat dalam kaitannya dengan identitas, kondisi dan aktivitas masyarakat, sebagai 'pengisi' dan 'pengguna' ruang tersebut. Justifikasi taman kota sebagai ruang publik seperti yang dibayangkan pada tujuan awal pembangunannya menjadi tak bermakna apabila ia bersebrangan dengan dorongan sosial masyarakat dalam beraktivitas. Representational spaces sendiri adalah hasil dialektika langsung antara representation of space dengan Spatial practice; aktivitas yang menunjukkan adanya relasi spasial antara objek dan produk, relasi antara antara objek dalam hal ini adalah taman dan saranaprasarana material - dengan produk sosial yang dibentuk oleh objek-objek tersebut.

Taman Alun-alun Bandung, digunakan pengunjung sebagai tempat bermain di akhir pekan, pengunjungnya sendiri berasal dari warga Kota Bandung maupun turis luar kota. Pada akhir pekan, Taman Alun-alun Bandung dibanjiri oleh orang-orang yang bermain bersama keluarga. Pada hari-hari biasa, 
aktivitas di Taman Alun-alun Bandung tersebut tidak seramai pada akhir pekan. Taman Alun-alun Bandung pada hari-hari biasa masih digunakan oleh turis dalam maupun luar kota yang sedang bervakansi, namun lebih sepi bila dibandingkan dengan akhir pekan. Letaknya yang menempel dengan masjid raya Bandung dan beberapa pusat perbelanjaan membuat ia menjadi tempat yang strategis untuk menjadi tempat singgah.

Syifa, mahasiswa perguruan tinggi negeri di Bandung yang sejak kecil tinggal dari Bandung menuturkan:

"Saya walaupun tinggal di Bandung sejak kecil, baru dua kali ke Taman Alun-alun. Pertama karena ingin melihat bagaimana bentuknya. Kedua, ketika mengantarkan saudara dari luar kota. Pada saat itu, saya sekaligus menemani saudara saya berbelanja pakaian dan jalan-jalan di Braga. Lumayan untuk duduk-duduk, pada saat itu kalau tidak salah ada kipas di beberapa sisinya, jadi lumayan sejuk. Tapi, sebenarnya tidak ada yang benar-benar menarik dari Taman Alun-alun, selain lapangan hijau, pedagang makanan, dan melihat orang beraktivitas masing-masing dengan keluarganya."

(Syifa, mahasiswa - wawancara)

Penggunaan tersebut pada akhirnya menjadi problematik apabila ditilik dalam dimensi ruang sosial, mengingat sebagai sarana vakansi ia adalah tempat di mana masyarakat sedang memberi jeda pada aktivitasnya, sedang melakukan eskapisme. Taman Alun-alun Bandung, menjadi ruang yang memberikan nafas kewarasan bagi mereka yang di hari-hari kerja harus tersengal-sengal karena aktivitas keseharian. Nafas-nafas kewarasan yang dihembuskan melalui aktivitas permainan keluarga; permainan sepakbola, balon sabun tiup, kincir terbang; konsumsi jajanan makananminuman; selfie bersama keluarga dst.

"Aku beberapa kali ke Taman Alunalun, buatku ya Taman Alun-alun adalah tempat untuk jajan. Kalau ada keluarga dari luar kota pasti aku ajak duduk-duduk di Alun-alun, selain karena banyak makanan, ia gabung dengan masjid, jadi nggak ribet untuk shalat-nya. Bisa untuk piknik-piknikan. Hanya saja, sayang banget karena rumput yang digunakan adalah rumput sintetis, sering banget bau kaki. Aku membayangkan park yang kayak di luar mestinya, rumputnya otentik, ndak artifisial, lebih segar."

(Putri, pekerja swasta, wawancara)

Namun, walaupun Taman Alun-alun Bandung dapat dilihat sebagai oase bagi mereka yang keringatnya diperas di hari kerja, lalu bagaimana dalam kondisinya sebagai sebuah ruang sosial yang dibayangkan, sebagai ruang publik yang dapat melampaui ruang tempat di mana kerumunan orang berada?

\subsection{K ondisi Ruang Publik Taman Alun- alun Bandung}

Taman Alun-alun Bandung tidak dapat dikatakan memiliki fungsi ideal sebagai ruang publik, apabila merujuk pada perhatian Habermas (1991) bahwa rasionalitas negara/publik (suatu kondisi prasyarakat ruang publik) dapat bekerja melalui kemampuan masyarakat untuk datang dan hadir secara politis melalui berbagai aktivitasnya ke dalam 'free discursive space' - ruang diskursif yang bebas. Spatial practices yang terdapat di Taman Alun-alun Bandung tidaklah dapat dikatakan menjadi aktivitas yang menunjang terciptanya idealisasi ruang publik. Dalam rutinitasnya, minim sekali ada aktivitas kepublikan yang menjadi bagian dari spatial practices di Taman Alun-alun Bandung. Taman Alun-alun Bandung pada waktu keseharian hanya dapat dilihat sebagai ruang tempat di mana 
masyarakat yang letih dari roda ekonomi sedang beristirahat, dengan aktivitasnya yang serba individual dan terkotak-kotak dalam sekat-sekat, ketimbang sarana bagi pengembangan demokrasi.

"Saya berkali-kali datang ke Taman Alun-alun, dari berkali-kali itu kebanyakan datang bersama istri, pernah hanya sama anak saja. Fokus utamanya ke sana pasti untuk bermain bersama anak, tidak ada yang lain. Mereka suka main bola dan balon. Saya dan istri biasanya ngeliat saja sambil makan bawaan dari rumah.

(Hikmat, pekerja swasta, wawancara).

"Saya heran kenapa rame banget, padahal cuman lapang aja, bau kaki juga. Saya sih jarang ke sini, paling kalau ada sodara yang minta anter ajak main dari luar kota. Saya ke sini sekarang, kebetulan aja sih, mlipir, abis shalat Dzuhur."

(Anton, ojek online, wawancara).

"Hiburannya di dekat Taman Alun-alun sebenarnya lucu-lucu, sering ada aktivitas komunitas cosplay misalnya kalau jalan sedikit ke depan gedung KAA (Konfrensi Asia Afrika). Tapi, bila pertanyaannya apakah ada kegiatan yang melibatkan warga dalam aktivitas di dekan Taman Alun-alun, sih sepertinya nggak ada. Kita biasanya hanya sekedar menjadi penonton, walau pernah juga aktivitas jalan sehat, dan tentunya didominasi oleh kelas menengah saja.?"

(Dimas, dokter, wawancara).

Apabila meminjam konsep Juergen Habermas terkait public sphere, indikator paling mendasar terciptanya nuansa kepublikan pada suatu ruang adalah, terjadinya partisipasi pluralitas publik dan konsolidasi publik pada suatu ruang tertentu yang melintasi kelas dan struktur sosial dilandaskan dan untuk mencapai emansipasi. Partisipasi pluralitas publik, yang memungkinkan terciptanya kegiatan bersama lintas kelas (sosial), terorganisir dan kolaboratif di suatu tempat, entah itu kegiatan seni yang berlanjutan, diskusi 'publik' atau kegiatan-kegiatan lain dengan tujuan deliberasi (Habermas, 1991). Kegiatan bersama lintas kelas, dapat diakomodir dengan keberadaan Taman Alun-alun Bandung yang ada, namun elemen-elemen di dalamnya tak dapat dikatakan melakukan sebuah tindak politik (dengan p- kecil) kolaboratif, tidak ada aktivitas partisipatif yang berarti dan berkontribusi pada rasionalitas publik, selain aktivitas vakansi.

Walaupun dalam pengakuannya, pemerintah memperbolehkan Taman Kota dipergunakan seluas-luasnya. Bahkan dijadikan sebagai tempat untuk menunjukkan ekspresi Politik (dengan P-besar), seperti yang dituturkan oleh Sugiyono:

Taman boleh digunakan oleh siapa pun selama mengajukan ijin pada kami dan ijin kami pun dijadikan dasar untuk perijinan kepolisisn. Maka taman atau ruang publik adalah milik masyarkat selama tidak bertentangan dengan hukum. (Iwan Sugiyono, wawancara)

Dalam posisinya di mata rantai kapitalisme, posisi Taman Alun-alun Bandung yang menjadi tempat singgah mereka yang berbelanja, dapat dilihat sebagai elemen penunjang roda konsumerisme. Seperti yang dituturkan oleh Lefebvre bahwa di dalam masyarakat dengan corak produksi kapitalistik, produksi ruang akan selalui memiliki orientasi pada kepentingan kapital: dengan dorongan utama pada aspek efisiensi dan efektifitas produksi dan sirkulasi komoditas. Pada posisi tersebut, Taman Alunalun Bandung adalah feeder dari praktik konsumerisme yang bekerja di berbagai pusat perbelanjaan.

Dari sana kita dapat melihat bagaimana Taman Alun-alun Bandung, tidaklah dapat 
dilihat secara naif, bahwa ia memiliki tujuan sebagai ruang demokratis semata, dan bahkan apabila idealisasi awal dari tujuan untuk membangun corak kepublikan di ruang publik menjadi hampa, kita dapat menerimanya sebagai sebuah konsekuensi produksi ruang yang banal. Lefebvre berargumen bahwa produksi sosial yang menghasilkan urban space (ruang urban) adalah fundamental/penopang dari proses reproduksi kapitalisme. Produksi sosial akan ruang, pada akhirnya rentan digunakan oleh kelas hegemonik (berkuasa) sebagai alat untuk menguatkan dominasinya. Dominasi yang terbangun dalam konteks Taman Alun-alun Bandung, adalah bagaimana Taman Alunalun Bandung sekadar menjadi tempat di mana leisure masyarakat menemukan objek penghasratannya, melalui aktivitas-aktivitas permainan, gimmick dan konsumerisme yang disodorkan di sekitar Taman Alun-alun Bandung tersebut, setelah melepaskan diri dari dimensi kepublikan ruang sosial.

Dialektika antara Representation of space dan Spatial practice pada akhirnya memang tidaklah benar-benar dapat 'ideal', menilik pada kondisi, bahwa ruang adalah arena di mana pertarungan antara berbagai pihak. Dalam masyarakat kapitalistik modern, semua pihak yang memiliki kepentingan akan mencoba untuk saling mendominasi pemakaian atau pemanfaatan atas ruang yang ada, dengan berbagai instrumen otoritatif, dan berupaya mereproduksi pengetahuan untuk mempertahankan hegemoni atas pemanfaatan ruang. Taman Alun-alun Bandung, pada akhirnya sebagai ruang bersama (common space) akan selalu menyesuaikan diri kebutuhan sirkuit ekonomi, di level personal atau di level rantai ekonomi yang lebih besar. Produksi ruang memiliki keterkaitan dengan perkembangan 'mode of production' masyarakat modern, di mana produksi pengetahuan mengenai ruang, secara spasial maupun sosial. Mengutip apa yang dituturkan oleh Lefebvre:
"Space is real in the same sense that commodities are real since (social) space is a (social) product" (Lefebvre 1991:26).

Dalam posisi tersebut, masyarakat sipil harus dapat merebut kembali ruang dari kooptasi motif-motif keekonomian, dan mengembalikannya pada corak-corak kepublikan.

\section{$5 \quad$ K esimpulan dan R ekomendasi}

Seperti yang telah di bahas, Taman Alunalun Bandung pada dasarnya adalah ruang yang coba yang coba diorientasikan dan difungsikan oleh pemerintah Kota Bandung sebagai wahana kepublikan. Sayangnya harapan tersebut, tidak seideal visi awalnya. Corak kepublikan yang tidak hadir di sana membuat Taman Alun-alun Bandung tidak layak disebut sebagai ruang publik, terutama bila menilik pada argumentasi Habermas terkait konsep tersebut.

Dalam tataran praksis, Taman Alun-alun Bandung berjarak dengan Social Practices partisipatif. Pemerintah sendiri, sebagai penyedia ruang, tidak memberikan dorongan dan tidak memfasilitasi aspek-aspek yang memungkinkan terciptanya ruang publik. Sehingga, pada akhirnya Taman Alun-alun Bandung tidak dapat dikatakan berhasil menjalankan fungsinya sebagai representational spaces bagi aktivitas partisipatif masyarakat, mengingat keberjarakan tersebut membuat kepublikan yang dibayangkan dapat mengisi ruang-ruang Taman Alun-alun Bandung tersebut tidak tercapai. Keberjarakan yang terepresentasi dari absennya aktivitas-aktivitas bersama yang seharusnya ada di ruang publik; aktivitas kolaboratif yang seharusnya signifikansinya dapat melampaui elemen-elemen dalam kerumunan yang memiliki kepentingannya masing-masing.

Terdapat perhatian khusus yang seharusnya diberikan bahwa seperti yang dikatakan oleh Lefebvre, kita tidak bisa melihat ruang sekadar sebagai place, atau teritori secara naif, namun kita harus 
memperhitungkan aspek sosial yang menjadi mesin pendorong dimensi kepublikan dari ruang tersebut. Dalam konteks Taman Alunalun Bandung sebagai ruang urban, apabila tujuan akhirnya untuk membangun ruang publik, maka yang perlu dilihat adalah bagaimana melepaskan dimensi sosial dari kooptasi sirkuit kapitalisme yang senantiasa menghantui. Sehingga tujuan akhir dari ruang publik, seperti yang dibayangkan oleh Habermas sekaligus Ridwan Kamil, dalam konteks ini Taman Alun-alun Bandung dapat menjadi tulang punggung berjalannya demokratisasi sosial yang tentunya deliberatif.

\section{Daftar Pustaka}

Bogdan, R. C., \& Biklen, S. K. (1982). Qualitative research for education: An introduction to theory and methods. Boston, Mass: Allyn and Bacon.

Fraser, N. (1990). Rethinking the public sphere: a contribution to the critique of actually existing democracy. Milwaukee, WI: Univ. of WisconsinMilwaukee, Center for Twentieth Century Studies.

Habermas, J. (1991). The structural transformation of the public sphere: An inquiry into a category of bourgeois society. Cambridge, Mass: MIT Press.

Kusno, Abidin. (2009). Ruang Publik, Identitas, dan Memori Kolektif: Jakarta Pasca-Soeharto. Yogyakarta: Penerbit Ombak

Lefebvre, H. (1991). The production of space. Oxford, OX, UK: Blackwell.

Website

Bayu, Jarot, Dimas. 2015. "Menuju "Kota Bahagia", Bandung Perbanyak Taman", http://properti.kompas.com/read/2015/ 02/04/232605821/Menuju.Kota.Bahag ia.Bandung.Perbanyak.Taman diakses 1 Desember 2017.

Saputra, Yuli, 2015. "Dua tahun Emil-Oded: Tidak hanya taman" daman http://www.rappler.com/indonesia/107 104-dua-tahun-kepemimpinan-ridwankamil-oded-danial diakses 2 Desember 2017.

Ramdani, Ridha, Alwan, 2016. "Ridwan Kamil sebut taman kota bisa lahirkan generasi toleran" http://bandungkita.net/2016/12/ridwan -kamil-sebut-taman-kota-bisalahirkan-generasi-toleran/ diakses 1 Desember 2017.

Riadi, Her, Joko, Tri, 2016. "Pemkot Gelontorkan Rp 42 Miliar untuk Revitalisasi Taman" http://www.pikiranrakyat.com/bandungraya/2016/04/12/pemkot-gelontorkanrp-42-miliar-untuk-revitalisasi-taman366515 diakses 2 Desember 2017.

Nursalikah, Ani, 2016. "10 Persen Warga Kota Bandung Hidup Miskin" http://nasional.republika.co.id/berita/n asional/daerah/16/04/06/o57bg236610-persen-warga-kota-bandung-hidupmiskin diakses 2 Desember 2017.

Jawa, Barat, Provinsi, BPS, 2016. “Tingkat Kemiskinan Jawa Barat September 2015" http://jabar.bps.go.id/new/website/brs ind/brsInd-20160104140758.pdf diakses 3 Desember 2017.

\section{W awancara}

Iwan Sugiono, Kepala Bidang Pertamanan DPKP3 Kota Bandung. 
J urnal Common | Volume 1 Nomor 2 | Desember 2017

Ismail Reza, urban planner - Pemerhati Tata Kota Bandung

Syifa, mahasiswa - Warga Bandung.

Putri, pekerja swasta - Warga Bandung.
Hikmat, pekerja swasta - Warga Bandung.

Anton, ojek online - Warga Bandung.

Dimas, dokter - Warga Bandung 